\title{
A TRAGÉDIA COMO UMA INSTITUIÇÃO DA POLIS
}

\author{
The Tragedy as a Polis' Institution \\ Ricardo Manoel Morais \\ IEC/PUC Minas, Brasil \\ ricardo_mom@hotmail.com
}

\begin{abstract}
Resumo:
O artigo visa analisar algumas pistas que sugerem uma relação entre as tragédias gregas e a polis, de modo a reforçar a hipótese de que a tragédia é, além de um gênero literário, uma instituição política. Para tanto, os trabalhos de Goldhill, Hall, Tierno, Vernant, são cruciais. Assim, são analisadas algumas condições de possibilidade para a emergência da polis democrática, na medida em que aclaram a relação desta organização sócio-política e da tragédia. Em seguida, será examinado o contexto fático nos quais as encenações trágicas ocorriam, apontando que tais eventos compunham uma preocupação institucional. Por fim, de modo a apontar uma ligação mais profunda, pretende-se refletir sobre alguns dos principais temas políticos das peças.
\end{abstract}

\section{Palavras-chave:}

Tragédia, Polis, Instituição política.

\begin{abstract}
:
The article aims to analyze some evidences that suggest an relationship between Greek tragedies and polis, in order to reinforce the hypothesis that the tragedy is more than a literary genre, but a political institution. Therefore, the works of Goldhill, Hall, Tierno, Vernant, are crucial. Thus, it analyses some conditions for the emergence of the democratic polis will, insofar as they clarify the relationship between this socio-political organization and the tragedy. Then, the factual context in which the tragic enactments took place will be examined, pointing out that such events were an institutional concern. Finally, in order to point out a deeper relationship than a mere contextual contingence, we intend to reflect on some of the main political themes of the plays.
\end{abstract}

\section{Keywords:}

Tragedy, Polis, Political Institution.

Recibido: 03/03/2021

Aceptado: 01/07/2021 


\section{INTRODUÇÃO}

Este texto tem como objetivo examinar alguns elementos e pontos de conexão entre a polis democrática e as peças trágicas. Isso porque, embora seja evidente que os festivais onde ocorriam as encenações trágicas compunham uma preocupação institucional, a relação entre as tragédias e a polis parece ser mais profunda que uma simples relação social. Noutros termos, ainda que seja um lugar comum sustentar que "o político" na Grécia remetia, etimologicamente, às questões relacionadas à polis, o que incluía todos os aspectos da vida dos cidadãos, dentre elas o teatro, tanto os temas quanto os eventos que circunscreviam as encenações das tragédias parecem evidenciar uma conexão profunda entre a polis democrática e a tragédia. Vale adianta que a relevância política da tragédia é uma questão corrente na literatura, da mesma forma que exames filológicos ou literários sobre esta questão. Há uma vasta literatura especializada na relação entre as tragédias gregas e a política, como Knox, Hall, Vernant, Vidal-Naquet, Tierno, Ahrensdorf, Goldhill.

Pretende-se demonstrar que ela seria um espaço privilegiado de tematização crítica da polis. A tragédia, ao refletir sobre tais temas, situa a polis em sua narrativa. Com isso, o primeiro item deste artigo se ocupa de analisar alguns elementos que levaram à emergência da polis. Embora a Grécia tenha tido outras experiências democráticas, a de Atenas foi se não a mais profunda, ao menos a mais bem documentada. Não é escopo deste trabalho problematizar, com profundidade, todos os elementos históricos, sociais e os processos políticos que diriam respeito à polis ateniense. Contudo, esta análise aclarará determinados temas.

Em seguida, serão examinados os rituais que circunscreviam as tragédias, pois este exame daria apontamentos de ser a tragédia uma instituição política. Ainda, para evidenciar que a relação entre as tragédias e a polis era mais profunda que a de uma relação entre a cidade e uma "festa cívica", serão examinados temas correntes nas tragédias que possuem íntima conexão com as questões da cidade (guerra, justiça), e a estrutura de muitas peças (similar às formas jurídicas).

\section{UMA BREVE COMPREENSÃO DA POLIS}

A polis, mais do que uma organização política, é o marco social da história da formação grega, sendo "[...] o centro principal a partir do qual se organiza historicamente o período mais importante da evolução grega" (Jaeger, 1995: 106107). Neste sentido, as várias dimensões e temas situados na Grécia - filosofia, processo de transformação social, vida comunitária - convergem para a polis. Por outro lado, se analisar e compreender a relação de proximidade e entre polis e tragédia é fundamental, deve-se ter claro que não se trata de estabelecer uma relação de causa e efeito ou de primordialidade, como se uma tivesse criado as condições para a outra ou fosse seu reflexo. Ao contrário, o objetivo é expor a questão de serem as tragédias uma instituição da polis ateniense.

O processo de consolidação da polis democrática é atrelado à abrupta urbanização ocorrida no mundo grego "[...] entre os séculos VIII e VII, urbanização para a qual contribuíram vários fatores, tais como a intensificação do processo tecnológico e artesanal, a passagem de uma economia natural (escambo) a uma economia 
monetária e em grande surto de atividades comerciais" (Oliveira, 2013: 31). Tal fenômeno viabilizou a formação de uma comunidade que se projetava para além de uma estrutura agrária e privada (oikos), levando a uma inevitável pulverização da autoridade monolítica do basileus. Com a dissolução gradual do mundo hierárquico do domínio arcaico, operou-se uma reestruturação da ordem comunitária que culminou na descentralização e coletivização do poder.

Ainda que "O aparecimento da polis [constitua], na história do pensamento grego, um acontecimento decisivo" (Vernant, 1992: 53), é necessário notar que a descentralização e coletivização do poder político -precedida da dissolução gradual do mundo hierárquico das soberanias arcaicas- não foi um processo natural e linear, mas, como o é todo deslocamento de poder, conflituoso e sujeito a idas e vindas. O contexto arcaico remete a uma comunidade aristocrática cuja hierarquia era "[...] tida por natural, de estruturas superpostas, em cuja cúspide dominavam um rei (basileús) e o conselho de nobres (áristoi)" (Tierno, 2014: 6). Uma sucessão de eventos que catalisou mudanças político-institucionais: a revolução em Corinto, com a derrubada do clã dos Baquiadas; a constituição de Esparta, onde Licurgo instaurou a lei constitucional; a codificação de Drácon e as reformas de Sólon. Estes episódios tiveram como denominador comum a substituição de uma elite aristocrática por outra. Entretanto, foi Atenas que obteve o maior sucesso no processo de reforma da sociedade e de suas instituições, aprofundando a participação popular (Tierno, 2014: 7).

Necessário "[...] salientar que, entre os gregos, Atenas não constituía nem constituiria a única pólis democrática, embora possa ser considerada, em perspectiva, o exemplo que deixou mais e melhores documentos e literaturas" (Tierno, 2014: 8). Apesar das vicissitudes, a polis, "[...] desde o seu advento, que se pode situar entre os séculos VIII e VII, marca um começo, uma verdadeira invenção: por ela, a vida social e as relações entre os homens temam uma forma nova, cuja originalidade será plenamente sentida pelos gregos" (Vernant, 2014: 53). A marca mais extraordinária que se consolidou com o advento da polis em Atenas foi a preeminência da palavra sobre os outros instrumentos de poder. Se para Arendt (2010) a violência é justamente o fator que oblitera qualquer possibilidade de uma real esfera política (que deve ter como marca central a igualdade e a liberdade, criando o terreno para que o discurso se coloque como a principal manifestação da ação política), também Vernant (1992) chama a atenção para a magnitude da supremacia da palavra na polis democrática.

Segundo Vernant (1992: 53-54), a emergência da polis seria um acontecimento decisivo, precisamente por suas repercussões tanto no plano intelectual quanto no das instituições políticas. E, embora a polis tenha se manifestado em múltiplas formas e em variadas etapas e sociedades desde o seu advento (entre os séculos VIII e VII), o seu estabelecimento foi marcado pela importante supremacia que a palavra assumiu em relação a outros instrumentos e dispositivos de poder. A palavra se torna o instrumento político por excelência, constituindo-se como a chave para toda a autoridade "legítima" do conjunto de instituições políticos. Organizando o comando e o domínio "válido" ou "consensual" de uns sobre outro. Desse modo, a palavra deixa de ser uma simples fórmula, assumindo o formato do debate, do enfrentamento dialógico, da discussão, da argumentação persuasiva e racional através da qual 
concepções de bem comum e meios para alcança-lo podem ser contrapostas. Através da palavra "[...] a vida social e as relações entre os homens tomam uma forma nova, cuja originalidade será plenamente sentida pelos gregos".

Segundo Arendt (2010), nos gregos, a liberdade só existiria na esfera pública, pois o domínio, a submissão ou a imposição pela violência não teria espaço no público, apenas no oikos. Ordem imposta, hierarquia, subordinação e violência eram elementos pré-políticos. Assim, a polis, por ser a esfera onde o humano agia politicamente, era o campo do agir político, do discurso, onde o homem se destacava do animal social. A política apenas é possível numa ordem que viabilize as potencialidades humanas para além da brutalidade animalesca da violência. $O$ público apenas se estabelece quando os humanos, pela ação e pela palavra, entre iguais, deliberam sobre questões que tangenciam a todos, sem emprego de força.

Arendt explica que o homem se divide entre duas esferas fundamentais, oikos e polis. A primeira, que se referia ao recinto familiar (que compreendia três gerações, escravos, gado e algum hóspede parente de um antepassado falecido), era constituída por uma gama de costumes. Tal esfera possuía um código de honra atrelado aos heróis homéricos: a glória, os princípios da justiça-vingança e a absoluta determinação dos acontecimentos pelo basileus. Pressupunha um herói capaz de arrebatar, com violência e astúcia, qualquer espaço de indeterminação. A esfera política, por outro lado, retrata a política ordenada. Se refere às ordenações das cidades, onde os cidadãos são partes de um todo e, como partes, devem se submeter às leis, instituições e aos deuses.

A cidade se compõe de lares, residências privadas que devem subsistir e se perpetuar para que haja a conservação do ser humano enquanto indivíduo e enquanto espécie. Para que um cidadão pudesse ser general, ele deveria ser proprietário de um bem na Ática, bem como pai de filhos legítimos. Com isso, esse indivíduo teria um patrimônio da defender. Por outro lado, a cidade não poder ser compreendida como um aglomerado de lares, mas é algo que os engloba e os nega ao mesmo tempo (Vernant, 2014: 275-276). Com efeito, polis e oikos não são esferas isoladas ou descontínuas. A segunda era a base econômica, biológica e social da primeira. $\mathrm{O}$ oikos produzia cidadãos pela reprodução, propiciando o bem-estar privado. Era a esfera natural sobre a qual se funda a polis, agindo como mediadora entre a crueza da natureza e a pureza cultural. Vernant (1992: 48-50) aponta elementos de continuidade entre a polis e o oikos: como uma ordem política não emerge "do nada", deve-se ter claro que a polis surgiu de uma sociedade estruturada no patriarcalismo do basileus (retratada nas épicas) e, de certa forma, as tragédias representariam este momento de tensão entre a crise da tradição e a emergência de um "novo", marcado, radicalmente, pela indefinição.

O "novo" é, no emergente horizonte político do humano, radicalmente contingente e indeterminado. Arendt expõe que o ser humano é o único ser que pode se imortalizar, não porque é um animal social, mas porque age com liberdade e entre iguais em uma esfera capaz de fazer ecoar na eternidade um feito político (o agir político). Neste sentido, o horizonte humano é a imortalidade e, na medida em que "imortais" não nascem todos os dias, aqueles que irão inscrever os seus nomes junto aos deuses serão aqueles que, no campo de indeterminação da ação política, agirem 
de modo extraordinário, ou seja, romperem com a tradição, com o que está dado, mas sempre a partir dela, pois o agir não parte "de lugar algum".

Um dos principais pontos de tensão entre o oikos e a polis é a indeterminação. $\mathrm{O}$ oikos tem um telos bem definido: suprir as necessidades e determinações biológicas. Há também uma clareza quanto aos meios necessários para atingir tal telos: a produção, a reprodução e a ordem hierárquica. Havendo substancial clareza acerca dos meios e dos fins a serem buscados, a violência e a subserviência não anulariam a realidade do oikos, considerando que não havia nada a se deliberar pelo discurso e uma ação a ser realizada entre indivíduos iguais. Logo, seria um espaço regido por uma ordem rígida estruturada abaixo do patriarca, não havendo igualdade ou liberdade, apenas ordem para que a administração privada seja eficiente em vista do telos.

Na polis, por outro lado, nem o telos nem os meios para alcança-lo são determinados. Por mais que se diga que o objetivo da política é o bem comum, o político se abre ao indeterminado quanto ao telos e aos meios, pois deve considerar o bem de e para todo o demos (todos são iguais e livre). Assim, os indivíduos devem deliberar, pois, por serem iguais, o "bem" de um cidadão não é superior ao "bem" de outros, devendo haver debate público. O momento em que um indivíduo se coloca numa posição de superioridade, acaba-se a política. E, se todos os homens humanos podem colocar suas ideias e deliberar igualmente, não havendo hierarquia preestabelecida, ninguém sabe, de antemão, o resultado de uma deliberação/ação política. Logo, a polis, por ser o humano um ser político e aberto ao horizonte de indeterminação, é a esfera na qual ele se projeta como tal. O ser humano só é humano quando é político.

O contexto em que emerge o trágico é aquele em que uma lacuna se constitui no coração social, ampla o suficiente para que a oposição entre polis e oikos apareça e estreita o bastante para que não esgarce o corpo comunitário. A atmosfera da tragédia é o político. O ambiente de tensão, apreendido pelos autores trágicos, ao abrir um campo de potencialidades indeterminadas, reflete a ação humana de modo a despertar no público indulgência e temor, sendo, por isso, uma produção comunicativa que conecta, pelos atores, o dramaturgo e os expectadores assim como o discurso retórico conecta (pelo logos) orador e auditório (Tierno, 2009).

\section{O TOM POLÍTICO DAS ENCENAÇÕES}

Se os festivais onde era apresentadas as peças trágicas denotam uma relação com a polis, pelo fato de ser um evento cívico de consideráveis repercussões na Grécia e na polis ateniense, esse entrelaçamento se mostra ainda mais profundo com o exame de tudo aquilo que circunscrevia as apresentações trágicas. Goldhill (2008: 61) chama a atenção para o fato de que não só a política é uma forma de representação, reproduzida por atores políticos, como as encenações trágicas eram verdadeiros atos políticos. E o teatro seria relacionado à polis não apenas por uma simples decorrência do fato de ser parte da vida dos cidadãos. Além de as tragédias problematizarem temas políticos, éticos, sociais, a instituição do teatro era análoga às instituições democráticas atenienses. Noutros termos, tanto há uma temática política aberta a temas "universais" nas peças (o que será trabalho no próximo subitem) como a 
dinâmica mesma das encenações trágicas colocava em evidência aspectos centrais da polis, das instituições políticas e das virtudes concernentes à vida pública.

A Grande Dionísia era a principal manifestação fática desse enlace entre a tragédia e a polis ${ }^{1}$. Estima-se que o público do festival era de até 17 mil pessoas. Para além do fato de que tal contingente se sobrepunha substancialmente em termos numéricos em relação à Assembleia e aos tribunais (que reuniam cerca de 6 mil cidadãos), a audiência da Grande Dionísia representava a organização sociopolítica da polis, evidenciando uma cena coletiva onde se forma o espaço público para o agir político. Isso porque a demografia da audiência, o modo como os assentos eram dispostos no teatro ilustravam uma espécie de "mapa político" da cidade. Lugares especiais reservados aos membros do conselho, diplomatas estrangeiros, sacerdotes, dignitários e aos efebos (Goldhill, 2005: 63-64).

Não obstante essa representação do mapa político da cidade se manifestasse nos festivais, o aspecto cívico era fortemente enfatizado na cerimônia de abertura da Grande Dionísia, sobretudo nos quatro principais rituais apresentados à mesma audiência de cidadãos que assistirá às encenações trágicas. Em cada um desses rituais há a promoção e a projeção de um ideal de participação política nos assuntos da polis, bem como uma imagem do poder e da glória da polis democrática ateniense. Essa ocasião não era apenas um pretexto para a valorização das virtudes cívicas, mas esta era a causa mesma dos festivais.

O primeiro ritual consistia em os dez generais, que eram as principais lideranças militares e políticas, derramarem uma libação de vinho em sacrifício aos deuses. Este ritual enfatizava o poder e a organização da polis em torno do festival. Demonstrava também a importância política da festa. O segundo ritual consistia no anúncio dos nomes dos cidadãos que beneficiaram o estado, expressando o louvor em servir a polis, reforçando a relação de obrigação entre indivíduo e comunidade. O terceiro ritual era um desfile que tinha por objetivo exibir toda a prata que era paga pelos estados ao Império. Tal cerimônia glorificava Atenas como potência política e militar. Era justamente para testemunhar essa exibição dos tributos pagos pelos outros estados que a presença dos embaixadores estrangeiros relevante. Além disso, era enaltecido o caráter imperial que a polis ateniense representava na região (Goldhill, 2005; Hall, 2010: 23-24). O quarto ritual era um desfile dos efebos cujos pais morreram a serviço do estado. Eles eram educados às expensas da polis e, atingindo a idade para assumirem suas responsabilidades cidadãs, eram apresentados no teatro com uma vestimenta militar. Nesse momento, esses jovens realizavam o juramento de lutar e morrer pelo estado, como seus pais. Após, eles eram convidados a ocupar lugares de destaque.

Segundo Hall (2010: 25-26), a significação que cada ritual lança luz sobre o conteúdo das peças. Os rituais realizados na tragédia assumiam significados particulares no imaginário do público que acabara de participar deles. Essa concessão

\footnotetext{
${ }^{1}$ Carter (2010: 52) coloca em xeque essa visão desenvolvida neste subitem segundo a qual as festividades que envolviam as tragédias seriam relevantes para se estabelecer um elo analítico entre as tragédias e a polis democrática ateniense.
} 
de armaduras aos órfãos fornece uma referência psicológica para certas cenas, como o encontro de Ajax com seu filho, em Ajax, onde a armadura ou a morte de um pai guerreiro situavam um foco dramático. Pode-se apontar o fato de Édipo, em Édipo rei, recorrer de forma reiterada ao seu feito de ter libertado a cidade de Tebas do monstro da Esfinge. Édipo utiliza o fato de ser um benfeitor de Tebas para justificar sua capacidade política. Já em Édipo em Colono, o herói, tendo se descoberto não como benfeitor, mas como causa da peste, não utiliza mais a sua "falsa benfeitoria" passada, nem mesmo para justificar o seu casamento com Jocasta como presente do povo tebano pelos seus serviços prestados. Também a articulação entre um forte sentimento cívico e o apelo às divindades nos rituais dos festivais é um elemento marcante nas peças, embora de forma distinta em cada um dos dramaturgos.

O fato de os festivais trágicos estarem enquadradas em cerimônias cívicas marcadas por substanciais participação popular e engajamento cívico mostram que estas encenações eram o ponto culminante de um evento político. Quanto à procissão, segundo Hall (2010: 24-25), a "geografia psíquica" internalizada por todos aqueles que dela participaram, a rota da periferia para o centro, passando pelos santuários de deuses locais significativos, fornecia uma estrutura mental sobre a qual se transplantará as experiências da Idade do Bronze para os espaços públicos do teatro. O papel de destaque dado a uma jovem mulher na grande procissão cívica rumo ao teatro, que também incluía filhas de metecos carregando jarros de água, deveria ser considerado pelos espectadores tal como as várias cenas de tragédias nas quais as mulheres realizavam rituais como a libação de Ismene com o objetivo de reparar a conspurcação de seu pai, em Édipo em Colono.

Se a tragédia expõe os medos, anseios do público, e enaltece os valores em conflito na polis, confrontando tais ordens, o conflito encontra-se na essência mesma da democracia. O conflito era parte da competição democrática: se, por um lado, ordem e concórdia eram essenciais para a comunidade, por outro, caso fossem impostos, poderiam levar à estagnação e à alienação política. Em Édipo em Colono, há uma representação tanto de embates "sadios" quanto de enfrentamentos que criam impasses intransponíveis. Quando Teseu derrota Creonte ao mostrar a injustiça de seus atos, o ateniense derrota o seu adversário alcançando a concórdia e permitindo a continuação da comunidade. Quando, por outro lado, Eteocles e Polinices mergulham Tebas numa guerra fratricida, há uma representação de um impasse político que leva à estagnação e à destruição da cidade.

Acerca da relação quanto ao caráter competitivo e adversarial fomentado pela polis, as encenações trágicas davam-se num ambiente de competição. Os dramaturgos submetiam suas propostas de peças a um magistrado (archon eponymos), encarregado das questões seculares e políticas relativas às tragédias. Essa submissão da peça ao magistrado ocorria um ano antes do próximo festival. Cada autor tinha de submeter uma "tetralogia", composta por três tragédias e uma sátira, que poderia ser apresentada em um único dia (Hall, 2010: 24-26). Embora não se saiba como o 
archon chegava ao veredito, sabe-se que o autor da peça vitoriosa no festival era escolhido por juízes vinculados à opinião popular do auditório ${ }^{2}$.

Após a seleção dos três autores trágicos, estes distribuíam seus principais papéis aos atores, selecionando o coro e o choregoi. Este era um indivíduo central para que as competições trágicas ocorressem, sendo quem financiava a produção, a manutenção, as fantasias e os ensaios do coro de cidadãos que estariam disponíveis para cada um dos trágicos. Embora nem todos os indivíduos quisessem tal função, essa contribuição era uma oportunidade para aumentar a reputação e impulsionar a carreira política, além de ser vista como uma grande honra e ocupar um lugar de destaque na procissão do festival (Hall, 2010: 20-22).

As bases econômicas para as tragédias eram profundamente relacionadas à vida política da cidade. A seleção do choregoi acontecia um ano antes do festival, pouco depois de o festival anterior terminar. Como a competição trágica era acirrada e este tipo de contribuição financeira era dispendiosa, havia uma pressão para a vitória por parte do choregoi, que instauravam mais um foco de competição à já aferrada concorrência pela vitória no festival. Cada um dos poetas concorrentes selecionados pelo archon tinha sua tetralogia executada de uma só vez em um único dia, sendo a ordem das apresentações decidida por sorteio. No final da competição, alguns cidadãos comuns (os "juízes"), escolhidos por um sorteio de última hora (com o objetivo de se evitar corrupção), deveria votar, sempre pressionados pela opinião pública, manifestada nos aplausos após cada uma das apresentações (Hall, 2010: 2026).

\section{TEMÁTICA DA TRAGÉDIA E A POLIS}

Com efeito, uma gama de temas relacionados não só aos processos políticos diretamente relacionados à polis eram colocados em debate, mas, igualmente, se jogava luz a questões ligadas à dinâmica sociopolítica da cidade. Neste sentido, podese destacar para análise algumas questões políticas tematizadas nas peças, questões estas que aparecem de forma mais ou menos recorrente: a forte relação entre a guerra, a polis, a cidadania e a tragédia; a presença determinante de personagens que não eram cidadãos atenienses em papéis de destaque nas peças (embora, sempre, interpretados por atores homens e cidadãos); o sofrimento daquele que tem de escolher entre dois bens, agindo em um terreno instável; a responsabilidade de um agente soberano de si e a contingência; o conflito e o sofrimento agônico do herói; e o problema de duas noções de justiça em conflito e igualmente sedutoras.

\footnotetext{
2 A simbologia desta vinculação da decisão de um indivíduo (que age publicamente e oficialmente) se faz sentir na narrativa das tragédias sofoclianas, pela acentuação do indivíduo que marcam suas peças. Em Édipo rei, quando Édipo impõe a si mesmo a sentença de seu exílio, ele o faz publicamente, quase como uma "prestação de contas" (Vernant, 2002) à sua busca pela verdade. Quando Édipo se coloca, perante todos os tebanos, como o indivíduo capaz de resolver a peste e punir seu causador, a sua linha de ação passa a se vincular à opinião de seu "auditório", não tendo ele outra opção a não ser punir a si mesmo quando ele se descobre como causa da peste.
} 
As tragédias emergiram de um contexto de inflexão, situando-se em um limiar entre a tradição e o por-vir. É relevante notar que as tragédias são marcadas por um vocábulo jurídico muito próprio de seu período. Embora a tragédia seja algo bastante diferente do debate jurídico, ela se situa em um limiar, bastante parecido com o caráter fronteiriço que é próprio ao direito. Isso porque, segundo Vernant (2002), o marco primordial central do advento da polis democrática é a centralidade que a palavra assumiu no campo político em detrimento de outras meios, como a violência, categoria esta marcadamente pré-política. O direito, nesse sentido, é o ponto de interseção entre a democracia e o mundo pré-democrático: é o direito uma instituição que se pauta em um embate de palavras, sendo este debate sucedido de uma deliberação popular, situada entre o puro decisionismo e a análise imparcial de argumentos, tendo como desfecho um jogo de coerções e violências. Neste sentido, pode-se compreender o direito como algo que é, por um lado, altamente refinado, propositivo, deliberativo, racional, argumentativo e, por outro, é algo primitivo, no sentido e forçar alguém a fazer algo, quase como um pai forçando seu filho, ainda criança, a algo que será parte de sua educação moral como um pedido de desculpas forçado.

Cumpre destacar o fato de que as tragédias colocam situações imanentes nas quais a dimensão abstrata da virtude (como a justiça) é incapaz de solucionar. Em Orestes, o herói é colocado numa situação na qual ele mata sua mãe por vingança, de modo a restabelecer seu lugar de direito. A tragédia é repleta de atos de violência compreendidos como justiça. Embora haja um desfecho com o estabelecimento de uma instituição apta a julgar de forma ordenada, evitando a continuidade dessa violência recíproca e em constante reprodução (Goldhill, 2005: 75), ainda assim a peça problematiza um dilema moral que acaba por refletir na esfera pública. Também as peças sofoclianas Édipo rei e Antígona não possuem um desfecho no que diz respeito a uma "solução" ou uma via mais acertada da justiça, considerando que a realização de uma determinada concepção de justiça foi o que levou ao desfecho trágico. Em Medeia a heroína é confrontada com o abandono e com uma situação de fragilidade, sendo uma estrangeira desamparada prestes a ser expulsa, ou seja, Medeia é colocada em um terreno instável de ações onde ela, de fato, comete atos de vingança que poderiam, numa concepção platônica, taxados de viciosos. Por outro lado, a heroína é alvo de uma cadeia de injustiças ${ }^{3}$.

Em Édipo rei, Édipo, ao buscar aquele que matou Laio para realizar justiça, encontrou-se como causa da peste. Além disso, ao adentrar em seu palácio, no final da peça, empunhando sua espada gritando por Jocasta, pode-se inferir que o herói iria mata a rainha caso ela ainda não tivesse tirado sua vida. E se Édipo foi um governante

\footnotetext{
${ }^{3}$ Embora não se possa estabelecer uma conexão a respeito desta questão deforma descuidada, a tragédia de Medeia impõe uma discussão presente em mais de um diálogo platônico, que consiste em saber se é pior sofrer ou causar uma injustiça. No Górgias, Sócrates diz que cometer uma injustiça é pior que sofrê-la, pois a injustiça é o maior mal da alma. Assim, libertar-se dela é beneficiar a alma, bem como pagar a justa pena pelo cometimento de uma injustiça é livrar-se deste mal. Por esta razão, a retórica é inútil no que tange à eudaimonia, pois ajudar a condenar indivíduos que tenham cometido uma injustiça os torna mais felizes, ao passo que ajudá-los a sair impunes, infelizes.
} 
justo, tendo sido reconhecido como tal pelo Coro e por seus interlocutores abertamente no início da peça, não seria absurdo pressupor que a sua forma de governar era justa e ordenada pela razão, sobretudo pelo modo como ele ascende ao trono. Já Creonte, quando se torna soberano, adota uma noção de justiça ligada à piedade, pautando seus atos e seus discursos por essa linha. O fato de Édipo e Creonte (e Antígona, que representa uma forma de piedade) terem, cada um a seu modo, encontrado um fim trágico, embora justo, evidencia uma aporia da concepção de justiça. A tragédia de Medeia, no mesmo sentido, aponta uma importante questão, que é também tematizada pelo Sócrates de Platão: o potencial de ação face ao sofrimento de uma injustiça profunda.

A própria questão da cidadania é central. Em Édipo rei, o herói apresentará toda uma justificativa para promover, legitimamente, a investigação sobre o assassinato de Laio. Segundo a lei ática, só seria possível que alguém promovesse uma acusação perante uma comissão de juízes caso fosse cidadão e, no caso do assassinato (que seria uma ação privada), caso fosse parente da vítima. Para isso, Édipo dirá que promoverá a investigação porque, tendo sido o assassinato também um regicídio, ele prestará um serviço a Laio, à família de Laio (que agora é a sua família) e a si mesmo. Logo, Édipo justifica a sua ausência de legitimidade política, justificativa esta que não seria necessária a um cidadão. Além disso, Édipo promete banir o assassino, o que significa retirar o status de cidadão daquele que tenha cometido o crime. Isso porque em Édipo em Colono, após ser perguntado pelo coro sobre qual seria a sua pátria, o herói responde que "fora desterrado", atribuindo-se, mais adiante, a condição de ápolis, de um sem pátria.

Vidal-Naquet (2014: 299-300) aponta, também sobre esta questão em Édipo em Colono, a indefinição da cidadania de Édipo. Ora, tendo ele chegado a Atenas como um ápolis, não fica claro se ele, após receber a proteção de Atenas pelo rei Teseu e pelo coro, qual o status de cidadania recebido. Com efeito, Édipo "se torna efetivamente um cidadão mas um cidadão de Atenas, não de Tebas, e sua cidadania começa e termina com sua morte misteriosa", aponta Vidal-Naquet. É interessante notar que a cidadania de Édipo é duplamente indefinida. Quando ele está a ponto de se tornar um cidadão em Corinto, como herdeiro do rei Políbo, ele tem questionada a sua origem, o que o leva a fugir. Em Tebas, a sua cidadania é, por vezes, apontada como algo frágil, sendo lembrado de forma reiterada o fato de ele ser, até onde se sabia, um estrangeiro que recebeu o trono de Tebas como dádiva pelos serviços prestados aos tebanos. E quando Édipo finalmente descobre a sua origem tebana, ele perde a sua cidadania ao ter de se auto banir. Mesmo em Atenas, Édipo é reintegrado a uma condição indefinida, próxima à de um cidadão, mas não de forma clara e somente pouco antes de sua morte ${ }^{4}$.

\footnotetext{
${ }^{4}$ Vidal-Naquet (2014: 299) ressalta a relação entre a indefinição da cidadania e a reintegração a este status em outras peças: "Estamos portanto em presença de uma variação sobre um esquema sofocliano bem conhecido, o da reintegração do herói: morto Ájax, vivo Filoctetes, ambos são reintegrados ao exército que representa a pólis. Édipo é também reintegrado, não à sua cidade, mas a Atenas, em sua morte e através dela".
} 
A indefinição da justiça e da cidadania aparece no que diz respeito à virtude, à guerra, à verdade e à relação/tensão entre indivíduo, família e sociedade. No que diz respeito à problemática da virtude, a tragédia de Medeia, de Eurípides, é especialmente marcante. A peça trata da vingança de uma estrangeira contra o seu marido, que a abandona para se casar com a filha de um rei. O que leva Medeia a protagonizar o enredo trágico da referida peça é a proteção de sua honra, bem como o fato de que o ato de traição de seu marido demanda justiça ${ }^{5}$. Quando o rei determina que Medeia deixe a cidade, a heroína vê um futuro de desonra para sua família. Jasão, seu marido, seria o culpado, pois sua sede de poder o levou a abandonar sua família. Medeia, sempre pela arte da retórica, convence o rei a deixar que ela fique mais um dia na cidade, o que será crucial para sua justiça.

A habilidade da heroína na arte do convencimento tem como escopo levar a cabo uma determinada concepção de justiça. $O$ ato de Jasão se sacrificar sua família, a sua base privada para que ele possa se colocar na comunidade, deixa claro que tal personagem carece da virtude de se honrar a família. Mais ainda, o fato de Medeia tomar a preservação de um valor político central, que é a honra, como o motor de sua vingança privada - noção que, antes da consolidação da polis democrática, se confundia com a noção mesma de justiça - aponta para um interessante paradoxo: é a virtude da honra que, ao ser protagonizada por uma mulher estrangeira, leva a um ato de justiça nos termos contrários à justiça institucional. Entretanto, diferentemente do que ocorre nos diálogos platônicos, em que há uma solução para um embate entre uma concepção aparente e uma concepção verdadeira de justiça e de virtude, a peça trágica deixa estes temas em aberto.

O mesmo se passa com a verdade. Em Édipo rei, a enquête colocou a ordem humana numa situação de protagonismo em relação à divina, na medida em que esta não foi suficiente para apontar a causa da peste. O poder humano é tão importante que o próprio título da peça é Édipo rei. Em todo o decorrer da narrativa, o que está em questão é essencialmente o poder de um homem, conquistado, como ele mesmo diz, pela sua inteligência e sem a ajuda dos deuses. E, para se manter soberano, Édipo confronta o saber humano ao divino, indo da profecia até o testemunho presente. Enfim, Édipo, ao constituir-se um sujeito de saber capaz de estabelecer a verdade, colocou-se na posição em que ele, por critérios estabelecidos por ele mesmo, constitui a verdade no poder. Assim, será o inquérito de Édipo, e não a direção divina, que comanda a entrada de personagens, convocando-as, bem como será o comando do rei que levará à verdade. Os deuses, por mais que não tenham sua existência questionada, possuem um papel ora central (já que a profecia se realiza) ora pouco importante (já que é Édipo quem assume o controle de toda a situação de modo a resolvê-la).

Retomando as tensões mencionadas anteriormente - entre uma justiça divina e uma justiça humana; uma justiça homérica e uma justiça racional; um julgamento/julgador divino e um julgamento/julgador humano; o recurso aos deuses

${ }^{5}$ Quanto à cidadania, em Medeia esta questão aparece. Medeia é uma estrangeira que, obrigada a deixar a cidade, apresenta o pleito de nela permanecer mais um dia, arquitetando sua vingança. 
e o recurso às testemunhas - pode-se dizer que a díke humana ainda não está consolidada, visto que Édipo incorre numa profecia. Por outro lado, é graças a ele, um humano, que a justiça divina se concretiza. Nos termos de Vernant e Vidal-Naquet (1999: 57), "contrariamente à epopeia e à poesia lírica, onde jamais o homem é apresentado enquanto agente, a tragédia situa, logo de início, o indivíduo na encruzilhada da ação, face a uma decisão que o engaja por completo [...] uma justiça que luta contra outra justiça".

O que é interessante notar é o agonismo que se instaura entre um julgador divino e o humano. O divino revela que Édipo é a causa da peste, o que remete a uma maldição lançada sobre Laio. E é Tirésias que diz que se Édipo pretende punir o autor dos crimes ele deve punir a si próprio. Não obstante, Édipo, sendo o julgador humano, irá sobrepor suas lembranças, as de Jocasta, assim como o testemunho de escravos sobre a palavra dos deuses. Se se pensar em Homero, fica claro que o julgamento divino (através do juramento, que ignora o testemunho) é o bastante, ao passo que no julgamento de Sócrates, com a polis democrática já consolidada, a sentença humana foi o suficiente. Entretanto, uma vez que as tragédias representam a tensão entre estes momentos, foi necessária a participação divina e a humana, o juiz divino e o humano, uma profecia e um testemunho de um escravo.

Além disso, ao mesmo tempo em que há a presença de um herói, alguém extremamente virtuoso, sábio e justo, sua virtude não é absoluta, mas colocada em perspectiva. Édipo não é mais o indivíduo que se destaca em absoluto do ordinário (como o herói homérico), mas é constituído pela realidade. A pressuposição de que o ser humano é um ser-com-os-outros no mundo, o que decorre de se dizer que há um ethos ou um conjunto de ações que constituem édipo, é uma pressuposição de uma comunidade política. A este respeito Ahrensdorf (2009: 25-27) aponta que a virtude elevada de Édipo, ainda que seja um elemento da peça, é aparente. Isso porque o herói não tenta resolver a peste por ser radicalmente altruísta, mas para assegurar a sua soberania e a sua representação de virtude - elemento destacado também por Foucault. Além disso, por vezes, Édipo oscila entre a máxima virtude e o vício como quando, depois de descobrir que Jocasta era sua mãe, ele entra em sua casa pedindo uma espada para mata-la, o que não ocorre por ela já ter suicidado. Outro ponto destacado é o fato de Édipo, ao descobrir que Políbio havia morrido, não parecer triste pela morte de seu suposto pai, mas feliz por não ter sido ele o seu causador (antes de descobrir que ele não era filho biológico do rei de Corinto). Ainda, há passagens em que Édipo se mostra ambicioso ou prepotente em excesso, mostrando uma hybris não compatível com a virtude de um herói. Mas, ainda assim, ele teria sido um governante justo, sábio e virtuoso, bem como salvador de Tebas.

As tragédias, ainda, jogavam com as tensões existentes na cidade no que diz respeito à questão étnica e à questão da heterogeneidade ou, noutros termos, o referido gênero colocava um debate sobre as relações e tensões entre povos de diferentes etnias, gregos, persas, egípcios, troianos. Com efeito, tal heterogeneidade de manifestava também no fato de que as tragédias foram o único modelo no qual mulheres e escravos não só assumiam um papel, como tinham protagonismo. Neste sentido, homens comuns apareciam com alguma frequência nas peças, como aponta Carter (2010: 53-55). Em várias peças (Orestes, Antígona, Édipo rei, Suplicantes) a 
função de mensageiro é desempenhada por escravos e por cidadãos comuns, geralmente pequenos agricultores. Em Édipo rei será pela fala de um escravo que a verdade será estabelecida. Em Antígona, o guarda representado é um escravo ou um soldado de classe baixa. As tensões aparecem de forma mais clara quando o "cidadão comum" cria uma relação de identidade com o demos em geral, compartilhando o mesmo sentido popular e coletivo em relação ao herói e à situação vivenciada na história trágica. Um exemplo "[...] de uma peça mais política - é o guarda em Antígona. Não está claro que ele compartilhe o sentimento de apoio popular a Antígona, mas ele compartilha o medo comum de falar diante do rei dele" (Carter, 2010: 55).

Segundo Hall (2010: 104), em todas as tragédias gregas há conflito e dissenso. Marcantes confrontos entre as personagens, guerras (entre cidades e guerras civis), embates entre as personagens e o Coro. Os interlocutores se enfurecem, bem como um Coro nervoso canta enquanto ocorre uma enfurecida batalha toma corpo de forma bem próxima. Eventos sangrentos, cadáveres dilacerados e campos de batalha eram marcas quase invariáveis do figurino. O conflito é sempre o ponto de partida para o dramaturgo. Além desse enredo contextualizado a partir de uma guerra (recente, incessante ou por ocorrer), as personagens homens estão, muitas vezes, vestidos para a batalha. Outras vezes, o coro é representado por soldados. A própria referência de Medeia de que preferiria ir à guerra três vezes é bastante sintomática, sobretudo pelo fato de que ela compara a guerra ao ato de dar à luz, sendo este muito pior ${ }^{6}$. Considerando que a guerra era parte da vida de um cidadão ateniense, comparações entre situações com os horrores de uma guerra elucidavam os conflitos.

Neste sentido, é na prática social e política que é a guerra ou o conflito que aparece uma polaridade. E se na guerra há um confronto aberto com uma resolução clara (um vencedor e um perdedor), nas tragédias há uma imprecisão. "Através do espetáculo trágico, a própria cidade se questiona. Ora os heróis, ora o coro, encarnam sucessivamente valores cívicos e valores anticívicos" (Vernant, 2014: 280). Assim, seja em um conflito dialógico, de valores, de justiças, de virtudes, seja em um conflito fático, bélico ou entre personagens em si ou em relação ao coro, o conflito e o sofrimento decorrente desse conflito são uma constante. É relevante inferir disso é o fato de que, conforme será aprofundado mais a frente, o conflito permanece aberto, não encontrando, no mais das vezes, um desfecho racionalmente claro.

Por fim, vale destacar a presença que o demos possui nas tragédias, para além de seu papel nas celebrações que antecediam as festividades das encenações, isto é, como o povo é representado nas próprias narrativas trágicas. A emergência da tragédia como um gênero teatral e literário na Grécia está diretamente associada à interação dialógica entre um ator e o coro. Teria sido Ésquilo quem primeiro inseriu o segundo

\footnotetext{
${ }^{6}$ Numa longa fala (v.258-283), Medeia expõe a fragilidade de seu sexo, que, com o dote, paga para servir a um marido que não escolhe, reclusa e sem reclamar, sob o risco de ser repudiada. A declaração de que preferiria três vezes ir à guerra a parir uma única vez é sintomática. Alinhando-a aos heróis da época, revela que não se adapta ao padrão feminino e que não irá se submeter às decisões masculinas, mas combatê-las (Kury, s.a.).
} 
ator e Sófocles, o terceiro ${ }^{7}$. Entretanto, estabelecer um paralelo direto entre as interações existentes na polis ateniense entre os retores e o público nos tribunais ou assembleias, embora seja tentador, pode levar a conclusões unilaterais. Carter (2010: 50-52), ainda que não a rejeite, aponta que tal abordagem serviria também à épica homérica, na medida em que se ocupa, igualmente, da relação entre as massas e determinados indivíduos. "Os reis homéricos, especialmente Agamenon, derivam seu poder e status do número de homens sob seu comando" (Carter, 2010: 51). Entretanto, esta relação é diferente nas tragédias. Se nos textos homéricos "povo" remete à noção de indivíduos reunidos, tendo como causa uma convocação de figuras da elite, nas tragédias o demos é capaz de se organizar e falar por si mesmo, ou seja, há um maior protagonismo.

O dramaturgo, diferentemente, das comédias, não reconhecia diretamente o público ou o demos. Diferentemente, há, nas tragédias, determinadas personagens que se colocam como "porta-vozes" do demos, ainda que de forma individualizada. Se as tragédias eram um espaço onde se viabilizava a participação ativa a determinados cidadãos ou não cidadãos, igualmente representavam a comunidade compreendida como uma coletividade. Quando se trata do coro e da participação direta do corifeu nos diálogos, a referida representação se mostra com um pouco mais de clareza. Entretanto, há personagens que podem ser considerados como o representante de todo o demos (Carter, 2010: 58-60), como o mensageiro, n'As Traquínias, e Teseu, em Édipo em Colono. Teseu pode ser compreendido não apenas como o representante dos cidadãos, mas como a personificação dos valores, virtudes e elevação cívica atenienses. Teseu toma todas as decisões em favor do povo ateniense.

\section{CONSIDERAÇÕES FINAIS}

A compreensão e a análise das tragédias -seja a partir de uma abordagem que busca compreender os elementos sociopolíticos que as circunscreveram, ou do imaginário daqueles expectadores que assistiram às encenações a partir de seu universo de valores e experiências, seja a partir de uma análise hermética, que estuda as peças tentando estabelecer as suas ligações internas, seus conceitos e suas problematizações apresentadas- é sempre um enorme desafio. Isso porque há uma tendência de se tentar decifrar a tragédia ou partindo da possibilidade de se adentrar no imaginário de um expectador ateniense, pressupondo uma objetividade absolutizante própria de uma determinada racionalidade moderna ou examinando-a com as lentes de um moderno. Evidentemente que uma série de problemas podem surgir a partir disso.

Com isso, pensar a tragédia sem incorrer - totalmente - em qualquer dessas tendências, por mais desafiador que seja foi o intento deste texto. Quando se tratou da relação entre as encenações trágicas, seus rituais, a geografia do teatro, a

\footnotetext{
${ }^{7}$ Knox (1983: 8-12) aponta que a grandiosidade de Sófocles foi a introdução de um terceiro ator, tornando possível a tragédia como o confronto de seu destino por um indivíduo heróico cuja liberdade de ação implica total responsabilidade. O terceiro ator viabilizou uma maior complexificação do herói em relação aos interlocutores, diálogos mais completos e uma maior presença "humana" no palco.
} 
simbologia da procissão, e com a polis, não se intentou estabelecer uma ligação ou um paralelismo descuidado entre as práticas políticas da cidade e a tragédia. Como decorrência de se estabelecer uma equivalência reflexiva entre realidade e teatro surgiria a questão colocada por Carter (2010): se a tragédia apresentada na Atenas democrática era "democrática", tragédias apresentadas em cidades governadas por tiranos deveriam ser "tirânicas". Entretanto, este artigo visou apontar algumas pistas para compreender a tragédia tanto a partir do universo do qual ela emergiu (a polis) e a partir de onde ela se desenvolveu. A pertinência da crítica de Carter está no fato de que não se pode inferir que os dramaturgos teriam por objetivo apresentar a realidade como um pré-logos.

\section{BIBLIOGRAFIA}

Ahrensdorf, P. (2009). Greek Tragedy and Political Philosophy: Rationalism and Religion in Sophocles' Theban Plays. Nova lorque: Cambridge University Press.

Almeida, L. (1999). Antagonismo entre a retórica e a filosofia no Górgias de Platão. Dissertação apresentada ao Departamento de Filosofia da Faculdade de Filosofia e Ciências Humanas da Universidade Federal de Minas Gerais. Belo Horizonte.

Arendt, H. (2001) A condição humana. Tradução de Roberto Raposo. 10 ed. Rio de Janeiro: Forense Universitária.

Carter, D. (2010). The demos in Greek tragedy. The Cambridge Classical Journal, 56, pp. 47-94. Disponível em: http://journals.cambridge.org/abstract_S1750270500000282. doi:10.1017/S1750270500000282. Acesso em 12 de abril de 2018.

Easterling, P., Knox, B. (orgs.) (1985). The Cambridge History of Classical Literature: Greek Literature. Cambridge: Cambridge University Press.

Ésquilo, Sófocles, Eurípides, Aristófanes (s.a.). O melhor do teatro grego: Prometeu Acorrentado; Édipo rei; Medeia; As nuvens. Edição comentada. Tradução e notas de Mário da Gama Kury. Editora Zahar. (livro eletrônico)

Goldhill, S. (2008). Greek drama and political theory. In. Rowe, C., Schofield, M. (2008). Greek and Roman Political Thought. Cambridge: Cambridge University Press.

Hall, E. (2010). Greek Tragedy: Suffering under the Sun. Nova Iorque: Oxford University Press Inc.

Jaeger, W. (1995). Paideia. Tradução de Arthur M. Parreira. Editora Martins Fontes. São Paulo.

Knox, B. (1993). The heroic temper. Los Angeles: University of California Press.

Kury, M. (s.a.). Notas. In. Ésquilo, Sófocles, Eurípides, Aristófanes. O melhor do teatro grego: Prometeu Acorrentado; Édipo rei; Medeia; As nuvens. Edição comentada. Tradução e notas de Mário da Gama Kury. Editora Zahar, s.a.. 
Ober, J., e Strauss, B. (1991). Drama, Political Rhetoric, and the Discourse of Athenian Democracy. In. Winkler, J. J., Zeitlin, F. I. (orgs.). Nothing to Do with Dionysos? Athenian Drama in Its Social Context. Princeton: Princeton University Press.

Oliveira, R. (2013). Polis e nómos: O problema da lei no pensamento grego. Belo Horizonte: Edições Loyola.

Platão (2011). Gógias. Tradução, ensaio e notas de Daniel Lopes. São Paulo: Perspectiva.

Sófocles (1990). Trilogia tebana: Édipo rei, Édipo em Colono, Antígona. Tradução do grego de Mário da Gama Kury. Rio de Janeiro: Zahar.

Tierno, P. (2009). Contingencia política e imitación trágica. Equipo Federal del Trabajo, v. 49, p. 57-67, 2009.

Tierno, P. (2014). Formação da polis e o surgimento da democracia na Grécia antiga: história e consciência da Atenas clássica. Hologramática (Lomas de Zamora), v. 21, p. 99-119.

Vernant, J. (2002). As origens do pensamento grego. Tradução de Ísis Borges B. da Fonseca. Rio de Janeiro: Difel.

Vidal-Naquet, P., Vernant, J. (2014). Mito e tragédia na Grécia Antiga. São Paulo: Editora Perspectiva. 